\title{
Inching toward universal nutrient disclosure
}

A proposed global standard for mandatory nutrition labelling would compel all food producers to articulate fat, protein, fibre, sodium, sugar and calorie content on the back of all processed food packages.

The proposed standard, which was ironed out during a Codex Committee on Food Labelling meeting in Ottawa earlier this month, will be submitted to the Codex Alimentarius Commission for approval in July. The commission was created in 1963 by the Food and Agricultural Organization of the United Nations and the World Health Organization (WHO) to develop food standards, guidelines and codes of practice to protect consumer health and ensure fair trade practices with regard to food.

Proponents have long hoped that a global standard for mandatory nutrition labelling laws would serve as an impetus to the $80 \%$ of 194 UN member nations who currently do not have official labelling requirements to introduce laws requiring nutrient disclosure (www.cmaj.ca/lookup/doi/10.1503/cmaj .109-3909).

The major change proposed by the committee is to mandate governments to make nutrient labelling compulsory for all food products, rather than just foods for which a marketing claim related to nutrients is made.

The nutrients that must be disclosed on a voluntary or mandatory (if a marketing claim was made) basis were finalized by the Codex committee in July 2011. The nutrients to be disclosed are energy value, protein, available carbohydrates, fat, saturated fat, sodium, sugars and any "considered to be relevant for maintaining a good nutritional status, as required by national legislation or national dietary guidelines." In the case of nutrients tied to a marketing claim, the portion tied to the claim must also be identified.

The manner in which the disclosure was to be made remained unchanged. Existing standards require protein, carbohydrates and fats be expressed in

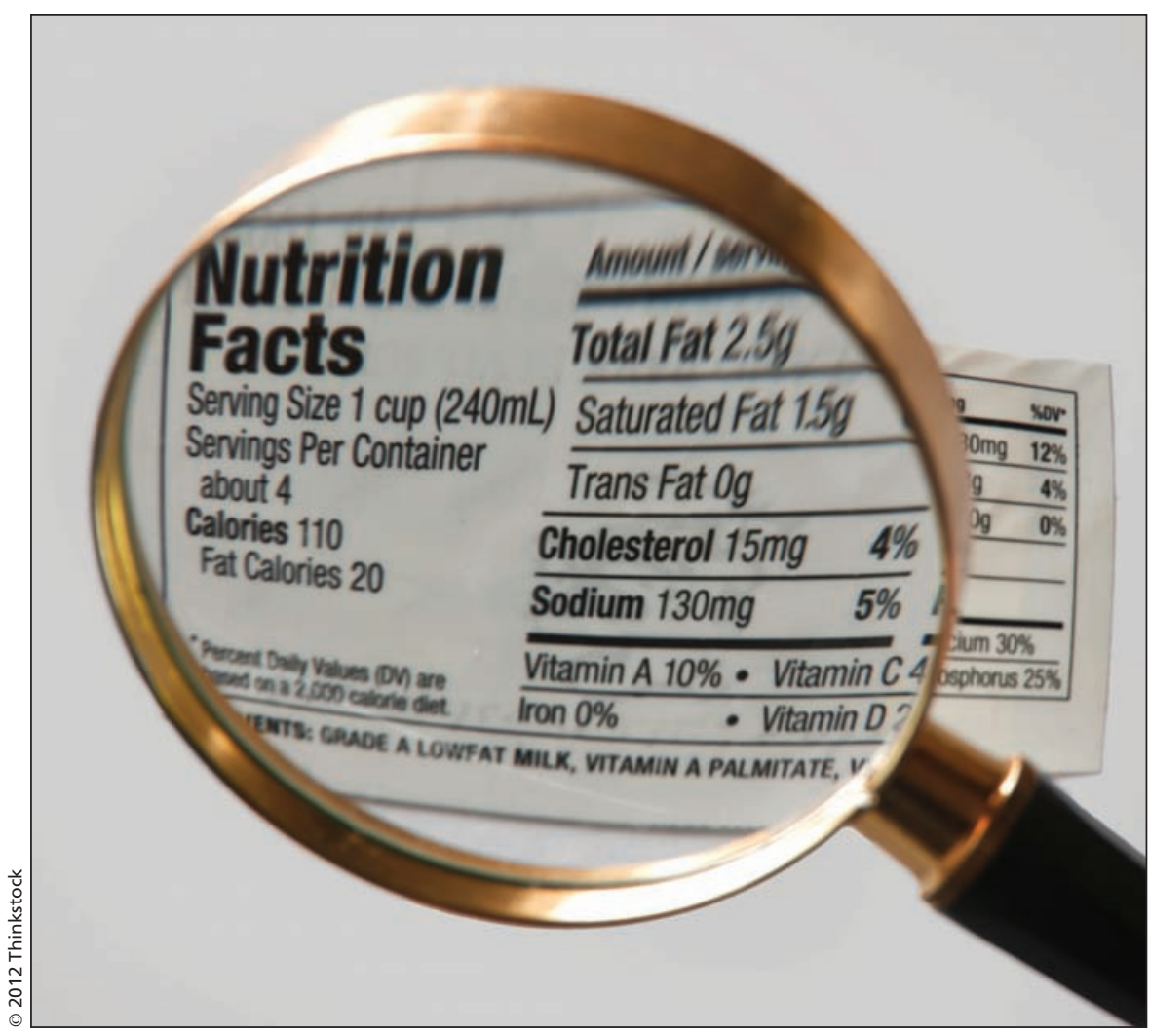

Proponents hope a global standard for mandatory nutrition labelling laws will serve as an impetus to the $80 \%$ of 194 UN member nations who currently do not have official labelling requirements to introduce laws requiring nutrient disclosure.

grams per 100 millilitres, per 100 grams or per package, while energy value must be expressed in calories and kilojoules per 100 grams or milliliters, or per package if it contains just a single portion. Nutrition content may also be listed per serving, if the serving amount is defined, or per portion, if the number of portions contained in the package is identified.

While extending nutrient labelling requirements to all foods, the committee rejected bids to move nutrition labels to the front of food packaging, which many believe is more readily understood by consumers and would have the greatest public health benefits.

"Inherent conservatism," coupled with industry resistance, proved the undoing of efforts to make front-ofpack nutrient labelling compulsory, says Bill Jeffery, national coordinator of the Centre for Science in the Public
Interest, who represented the International Association of Consumer Food Organizations at the Ottawa negotiating session. "We hoped that the committee would at least recognize that there's a kind of obvious benefit of seeing the information on the front of package instead of on the back of packages. Surely that doesn't require a lot of research or experience at the national level, but they were unprepared to accept that, and it's because there's a kind of inherent conservatism built into the decision-making process."

The process for revising Codex standards relies heavily on national experience, resulting in "an average approach that's consistent with international practice" rather than an approach that pursues "the optimum public health goal," Jeffery argues. "That's a real problem if we're trying to encour- 
age companies around the world to really properly address chronic disease prevention."

That means change can't be achieved until a sizeable number of governments support a revision and in the case of the proposed global standard for mandatory nutrition labelling, nothing would have been achieved had not the 27 member states of the European Union been onside as a consequence of their decision to mandate nutrition labelling in 2011, Jeffery adds.

Although several nations are currently examining front-of-package nutrient labelling systems, it hasn't yet taken international traction, Jeffery says. "I think there's a broad recognition that front-of-pack nutrition labelling does have some important public health benefits, and I think we'll probably start to see some countries around the world embracing it in the coming few months and years, but I don't think we can wait two decades before this realization is accepted in international law. It involves too much loss of life - easily preventable loss of life, like ensuring that consumers get readily accessible information about the nutritional composition of foods on the label ... It just seems obvious that it should be there, but there's so much resistance from industry."

The need for change is so compelling, though, that a more pro-active approach to food labelling should be adopted, similar to that of the WHO's Framework Convention on Tobacco Control, Jeffery argues.

"I think if we had to rely on the Codex standards to embrace front-ofpack labelling, it would be a major waiting game," he says. "It could take another two decades and maybe longer." — Michael Monette, CMAJ

CMAJ 2012. DOI:10.1503/cmaj.109-4215 